\begin{tabular}{c} 
International Journal of Scientific World, $4(2)(2016) 37-39$ \\
International Journal of Scientific World \\
SPC \\
Website: $\begin{array}{c}\text { ww. sciencepubco.com/index.php/IJSW } \\
\text { doi: } 10.14419 / \text { ijsw.v4i2.6156 } \\
\text { Research paper }\end{array}$ \\
\hline
\end{tabular}

\title{
Isolation of potential bacterial pathogens from the phylloplane of some selected medicinal plants
}

\author{
Haruna Y. Ismail *, Hauwa S. Bello., Ibrahim A. Allamin, Elizabeth Danjuma \\ Department of Microbiology, University of Maiduguri, Borno State, Nigeria \\ *Corresponding author E-mail:yismailh@gmail.com
}

\begin{abstract}
Microorganisms are ubiquitous and their impact could be appreciated directly or indirectly. This study was aimed at determining the occurrence of pathogenic bacteria on the phylloplane of some medicinal plants commonly used to treat diseases by oral administration. Leaves samples were collected aseptically from Cassia fistula (Cassia) Mangifera indica (Mango) and Psidium guajavum (Guava) and their bacterial contents were assessed. Higher bacterial counts were observed in raw samples followed by those washed with sterile water. Samples washed with sterile warm water (blanched) were shown to have lower counts although without statistical significance ( $\mathrm{p} \leq 0.05$ ). Guava leaves had higher counts $(3.4 \times 106 \mathrm{cfu} / \mathrm{g})$ in the raw samples and cassia in blanched $(6.4 \times 105 \mathrm{cfu} / \mathrm{g})$. However, mango leaves had the lowest $(8.4 \times 105 \mathrm{cfu} / \mathrm{g}$ and $2.0 \times 105 \mathrm{cfu} / \mathrm{g})$ in both the treatments respectively. Twenty bacterial species were isolated comprising Gram negative and Gram positive species. Bacterial identification revealed that Proteus mirabilis (35\%), Proteus vulgaris (15\%), Escherichia coli (15\%), Klebsiella pneumoniae (5\%), Morganella morganii (5\%), Salmonella typhi (10\%), Enterobacter sp. (5\%), Staphylococcus aureus $(5 \%)$ and Vibrio cholarae $(5 \%)$ were the prevalent species. These organisms could be potential pathogens and proper washing with hot water may serve a better means of reducing the microbial contents and thus, it is recommended.
\end{abstract}

Keywords: Phylloplane; Medicinal; Plants; Bacteria; Washing.

\section{Introduction}

Medicinal plants have for long, been remedies against human diseases because they contain components with therapeutic value [1]. According to the world health organization, over $80 \%$ of the world's population or 4.3 billion people, rely upon such traditional plant-based systems of medicine to provide them with primary health care [2]. The use of plants for treatment of various ailments is considered one of the important means of health care system. Two years back, there were many claims by scientists and herbalists that, use of some plant extracts could cure the deadly Ebola infection that caused epidemics in some West African countries including Nigeria.

However, the use of plants as medications could lead to health hazards instead of cure, especially in rural communities where exclusive dependence on these medications is not a mere speculation but reality. Plant leaves are consumed without proper treatment or washing that can help eliminate or reduce the microbial load. This type of treatment can rather cause more havoc to the consumer or might lead to emergence of new infection(s) [3].

With the current situation of health care systems in most rural communities, which involve consumption of different parts of plants materials; determining the occurrence of pathogenic bacteria is highly essential. This is due to the fact that bacteria are known to cause infections and their occurrence is ubiquitous. Many studies have reported the occurrence of microbes on the phylloplane of plants among which are members of enterobacteriaceae, Bacilli and Pseudomonads [4], [5] and could be potentially pathogenic. Investigating the possibility of having pathogenic bacteria on some of medicinal plants' phylloplane is crucial in order to prevent complications instead of recovery from infections. This will enable us create awareness among public on the better way of leave treatment before being used for medication to prevent the impending health risks.

\section{Materials and methods}

This study was carried out in the Microbiology laboratory, Department of Microbiology, University of Maiduguri, Borno State (coordinates: $11.83^{\circ} \mathrm{N}, 13.15^{\circ} \mathrm{E}$ ), Nigeria; between July and September, 2014. Leaves samples were collected from three different types of plants in the University Garden. The plants include Cassia fistula, Mangifera indica and Psidium guajavum. Triplicate samples were aseptically collected from each of the plants at random and conveyed to the laboratory immediately.

Samples collected were divided into three (3) groups and analyzed as described by [4], [6] with modifications. In the first group (G1), the samples were vigorously shaken in order to remove dust and suspended particles. Three pieces of each of the leaves samples were aseptically homogenized into a single paste and serially diluted by measuring one gram $(1 \mathrm{~g})$ and suspending it into $9 \mathrm{ml}$ sterile distilled water. After the dilution, $0.1 \mathrm{ml}$ aliquots of $10^{4}$ dilutions were inoculated into Nutrient and MacConkey agar and incubated at $37^{\circ} \mathrm{C}$ for 24 hours. For the second (G2) and third groups (G3), the samples were treated the same way except that, sterile and sterile warm water were used to wash the samples respectively before homogenization. The colonies that emerged were enumerated and expressed as colony forming units per gram. Isolation of pure colonies was achieved by repeated subculture on nutrient agar and characterized later according to the methods of 
[7] and [8]. The isolates were identified by their colonial, morphological and biochemical characteristics as outlined by [9] and [10].

\section{Results and discussion}

Results for bacterial enumerations showed the occurrence of large bacterial cells on the phylloplanes of the leaves samples. In G1 treatment, bacterial counts were more prominent compared to G2 and G3. $M$. indica had the lowest counts in all the treatments whereas $P$. guajavum had the highest. $C$. fistula was shown to contain $1.36 \times 10^{6} \mathrm{cfu} / \mathrm{g}, 1.28 \times 10^{6} \mathrm{cfu} / \mathrm{g}$ and $6.4 \times 10^{5} \mathrm{cfu} / \mathrm{g}$ in the unwashed (G1), washed (G2) and blanched (G2) samples respectively (Fig. 1). Similarly, there was steady decline in the bacterial load observed in the phylloplane of $M$. indica where highest number $\left(8.4 \times 10^{5} \mathrm{cfu} / \mathrm{g}\right)$ was observed in the unwashed samples. However, there was drastic decline in the bacterial count in $P$. guajavum in which $3.40 \times 10^{6} \mathrm{cfu} / \mathrm{g}$ and $4.4 \times 10^{5} \mathrm{cfu} / \mathrm{g}$ were recorded as the highest and lowest values respectively (Fig. 1).

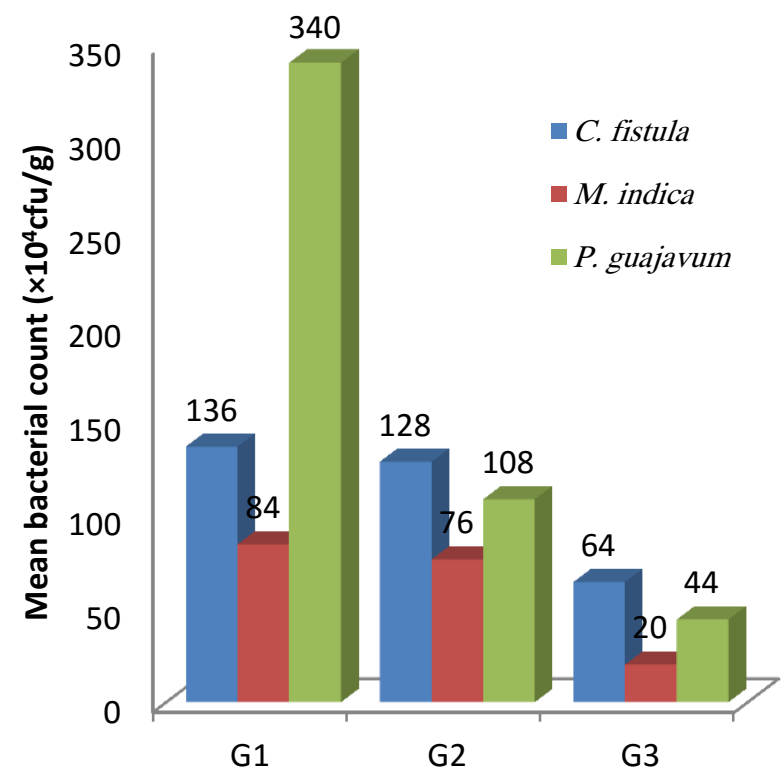

Fig. 1: Bacterial Counts.

Statistical analysis indicated a significant difference between treatments in a particular leaves sample $(\mathrm{p} \leq 0.05)$ but insignificant among leaves type.

The occurrence of large number of bacteria on the plants' phylloplane was never unprecedented due to the fact that bacteria are ubiquitous and many are known to be epiphytic. This agreed with the findings of [4] and [11] who observed the presence of microorganisms on phylloplane of different plants using culture and microscopic techniques respectively. Their presence also suggests the availability of basic carbon and energy requirements for microbial life and possible symbiotic relationship [12].

Washing of leaves with warm water (G3) was shown to considerably reduce the bacterial load on the leaves when compared with the unwashed. This indicated the ability of warm water to displace more bacterial cells than cool water; and might be a result of having more de-waxing ability of leaves cuticles by the warm water. Alternatively, the warm water facilitated the dissolution of exopolysaccharides synthesized by the microbes for improving adhesion, aggregate formation or protection from desiccation. This is supported by the work of [13] who observed the presence of exopolysaccharides as major contributor to colonization and survival of bacterial cells on phylloplane.

Lowest bacterial counts (Fig. 1) were observed in $M$. indica as against $C$. fistula and $P$. guajavum. This might be attributed to the fact that $C$. fistula and P. guajavum have rough phylloplanes that enabled easy attachment of large number of microorganisms on the surfaces. The work of [14] have suggested many factors that influence the abundance and diversity of phylosphere microbes in which plant type was a major determinant.

However, despite the reduction in bacterial load by seasonal influence (lower bacteria in summer than in winter [4]) and washing with warm water, the bacterial count recorded was still of great health concern. This is due to the fact that the values observed in G3 are above the limits outlined by some international organizations like World Health Organization (WHO), American National Standard for Dietary Supplements (ANSI), United State Pharmacopeia (USP) and American Herbal Products Association (AHPA) [15]. The standards set by the above organizations ranged between $10^{4} \mathrm{cfu} / \mathrm{g}$ and $10^{5} \mathrm{cfu} / \mathrm{g}$ in raw materials, powdered extracts or powdered ingredients of botanical origin intended for oral administration.

Bacterial characterization and identification revealed that most of the isolates were members of the family enterobacteriaceae. Many studies have revealed the presence of enterobacteriaceae as members of phylloplane communities [6], [16], [17], [18]. Proteus mirabilis was shown to be more abundant $(35 \%, \mathrm{n}=20)$, followed by $P$. vulgaris $(15 \%)$ and Escherichia coli $(15 \%)$. Salmonella typhi had 10\% occurrence while Klebsiella pneumoniae, Morganella morganii, Vibrio cholarae, Enterobacter sp and Staphylococcus aureus had 5\% occurrence each. Figure 2 provides a diagram showing percentage occurrence of the isolates.

The presence of enterobacteriaceae in general and some of these isolates in particular on plants' phylloplane have been stated severally by some investigators, thus supporting our findings. For instance, the occurrence of $K$. pneumoniae [17], Enterobacter sp [4], [6], E. coli [16] and Staphylococcus sp [4] have been reported. All of the isolates could be pathogenic due to the fact that the pathogenicity of strains of these species is well-known documented. Of particular interest, demonstration by [16] that some of phylloplane bacteria contain different antibiotic resistance genes could increase the health risks associated with these bacteria. 

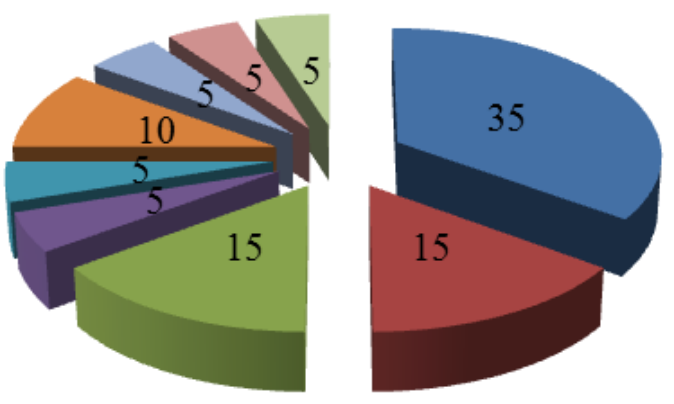

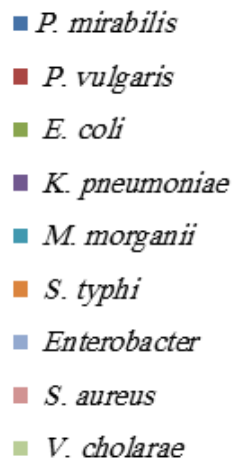

- P. mirabilis

P. vulgaris

- E. coli

- $K$. pneumoniae

Morgani

S. typhi

- S. aureus

- V. cholarae

Fig. 2: Percentage Occurrence of Phylloplane Bacteria.

In addition to the bacterial load, the identity of the bacteria strongly suggests the risk associated with consuming such preparation as medicaments. Some international organizations have strict limits for the presence of potential pathogens in herbal medicines. The Association of South East Asian Nations (ASEAN) for example, have limited the number of E. coli to $10^{3} \mathrm{cfu}$ in $1 \mathrm{~g}$ or $1 \mathrm{ml}$ and total absence of Salmonella in $25 \mathrm{~g}$ or $25 \mathrm{ml}$ preparations for oral administration [19]. Similarly, WHO have completely ruled out the presence of the two organisms in some herbal preparations [20].

\section{Conclusion}

In the present study, large number of bacteria were observed to be occupying the phylloplanes of $C$. fistula, $M$. indica and $P$. guajavum. All of the bacterial species present were members of the family enterobacteriaceae, with the exception of Staphylococcus aureus - the only Gram positive species. The number of the organisms and their identities clearly demonstrated their health associated risks due to their pathogenic potentials. Washing with warm water reduced the bacterial load insignificantly and also above the limits stipulated by regulatory bodies. Therefore, a better method for eliminating potential pathogens (e.g. using boiling water) is required for proper medication and to avoid further infection leading to complication. Hence the need for enlightenment campaign especially in rural communities where sole dependence on plant-derived medicine is common.

\section{References}

[1] Nostro, A., Germano M.P., D’Angelo, A., Marino, A., Cannatelli, M. A. Extraction methods and bioautography for evaluation of medicinal plant antimicrobial activity. Letters in Applied Microbiology; 30(5), (2000), 379-385.http://dx.doi.org/10.1046/j.1472765x.2000.00731.x.

[2] Bussmann, R. W., Glenn, A. and Sharon, D. Healing the body and soul: Traditional remedies for "magical" ailments, nervous system and psychosomatic disorders in Northern Peru. African Journal of Pharmacy and Pharmacology 4(9), (2110), 580-629.

[3] Ogunshe, A. A. O., Fasola, T. R. and Egunyomi, A. Bacterial profiles and consumer preference of some indigenous orally consumed herbal medications in Nigeria. Journal of Rural and Tropical Public Health 5, (2006),27-33.

[4] De Jager, E. S., Wehner, F.C. and Korsten, L. Microbial Ecology of the Mango Phylloplane. Microbial Ecology; 42, (2001), 201-207 DOI: $10.1007 / \mathrm{s} 002480000106$.

[5] Ilorin, M. O., Ahmed, O. O., Ezeani, C. J., Sara, O. and Adebusoye, S. A. Occurrence Microorganisms and Growth Potentials of Hydrocarbon Degrading Bacteria on the Phylloplane of some Tropical Plants" African Journal of Biotechnology 5(7), (2006), 542-545.

[6] Makhado, N. A. Epiphytic and endophytic members of the Enterobacteriaceaeassociated with healthy Eucalyptus trees. A Master's Thesis submitted to the University of Pretoria, South Africa. (2006), Pp $31-40$.

[7] Benson, M. Microbiological Applications Laboratory Manual Eighth edition, McGraw-Hill Companies, (2001), New York.
[8] Prescott, L. M. and Harley, J. P. Laboratory Exercise in Microbiology. 5th edition McGraw-Hill Companies, (2002), NewYork.

[9] Barrow, G. I. and Feltham, K. A. Cowan and Steel ${ }^{\text {ee }}$ s Manual for Identification of Medical Bacteria. 3rd edition. (1993), Cambridge University Press, London.http://dx.doi.org/10.1017/CBO9780511527104.

[10] Steffens, A. Identification Flow Chart, Bergey's Manual for Determinative Bacteriology. (2011), Available at www.uiweb.uidaho.edu/micro_biology/250/IDFlowcharts.pdf. Last accessed: 9/17/14.

[11] Hallett, C. K., Boyd-Wilson, S.H.and Everett, K. R. Microscope methods for observation of the phylloplane flora. Inc. Tools for Studying Pathogens. New Zealand Plant Protection 63, (2010)1523.

[12] Trouvelot, S., Héloir, M. C., Poinssot, B., Gauthier, A., Paris, F. and Guillier, C. Carbohydrates in plant immunity and plant protection: roles and potential application as foliar sprays. Frontiers in Plant Science 5: 592.http://dx.doi.org/10.3389/fpls.2014.00592.

[13] Monier, J. M. and Lindow, S. E. Differential survival of solitary and aggregated bacterial cells promotes aggregate formation on leaf surfaces. Protocols of National Academy of Science U.S.A. (2003), 100,

15977 15982.http://dx.doi.org/10.1073/pnas.2436560100.

[14] Bringel, F. and Couée, I. Pivotal roles of phyllosphere microorganisms at the interface between plant functioning and atmospheric trace gas dynamics. Frontiers in Microbiology 6, (2015), 486. http://dx.doi.org/10.3389/fmicb.2015.00486.

[15] AHP. Microbial Limits for Botanical Ingredients. American Herbal Product Association, (2014) 2014.

[16] Schnabel, E. L. andJONES, A. Distribution of Tetracycline Resistance Genes and Transposons among Phylloplane Bacteria in Michigan Apple Orchards. Applied and Environmental Microbiology; 65 (11), (1999) 4898-4907.

[17] Hashidoko, Y., Itoh, E., Yokota, K., Yoshida, T. and Tahara, S.Characterization of Five Phyllosphere Bacteria Isolated from Rosarugosa Leaves, and their Phenotypic and Metabolic Properties. Bioscience, Biotechnology and Biochemistry; 66 (11), (2002), 2474-2478.http://dx.doi.org/10.1271/bbb.66.2474.

[18] Reisberg, E. E., Hildebrandt, U., Riederer, M., and Hentschel, U. Distinct phyllosphere bacterial communities on Arabidopsis wax $\begin{array}{lllll}\text { mutant leaves. PLoS ONE } & & \end{array}$ e78613.http://dx.doi.org/10.1371/journal.pone.0078613.

[19] ASEAN. ASEAN Guidelines on Limits of Contaminants for Traditional Medicines and Health Supplements. 24th ASEAN Traditional Medicines and Health Supplements Scientific Committee Meeting (ATSC) 26th - 27th August 2014, Bangkok, Thailand and Endorsed at the 22nd ACCSQ Traditional Medicines and Health Supplements Product Working Group (TMHSPWG) Meeting 13th -14 th November 2014, Vientiane, Lao PDR.

[20] WHO (2007). WHO guidelines for assessing quality of herbal medicines with reference to contaminants and residues. Geneva: pp. 1228. 